Matematikai Közlemények

IV. kötet, 2016

doi:10.20312/dim.2016.03

\title{
Automatikus kiértékelő program ionogramok értelmezéséhez
}

\author{
Kalmár János \\ MTA CSFK GGI \\ kalmar@ggki.hu
}

\begin{abstract}
ÖSSZEFOGLALÓ. Az ionoszondák (speciális radarok) előállította ionogramok adnak tájékoztatást az ionoszféra aktuális állapotáról és szerkezetéről [4], melyből a rádióhullámok terjedési sajátosságaira és az üridőjárásra (pl. napkitörések) következtethetünk. A tanulmány bemutatja az ionogramok automatikus kiértékelését végző, a szerző által írt programot.

ABSTRACT. Ionograms produced by ionosondes (special radars) provide information on the instantaneous state and structure [4] of the ionosphere. This information can be used to infer radio propagation characteristics and effects of space weather events (eg. Solar flares) on the Earth's upper atmosphere. This study introduces a software developed by the author for automatic processing of ionogram.
\end{abstract}

\section{Bevezetés.}

$\mathrm{Az}$ ionogramokat ionoszondák állítják elö: széles frekvenciasávon (1-16 MHz) rádiójelekkel 'bombázzák' az ionoszférát, és (mint a radar) mérik az ionoszféra réteghatárokon visszavert jelek által megtett utat, vagyis a visszaverő felület magasságát. A mérés eredménye lényegében zajos digitális képként (1. ábra) jelenik meg, melynek értelmezése még gyakorlott kiértékelőnek sem egyszerü feladat.

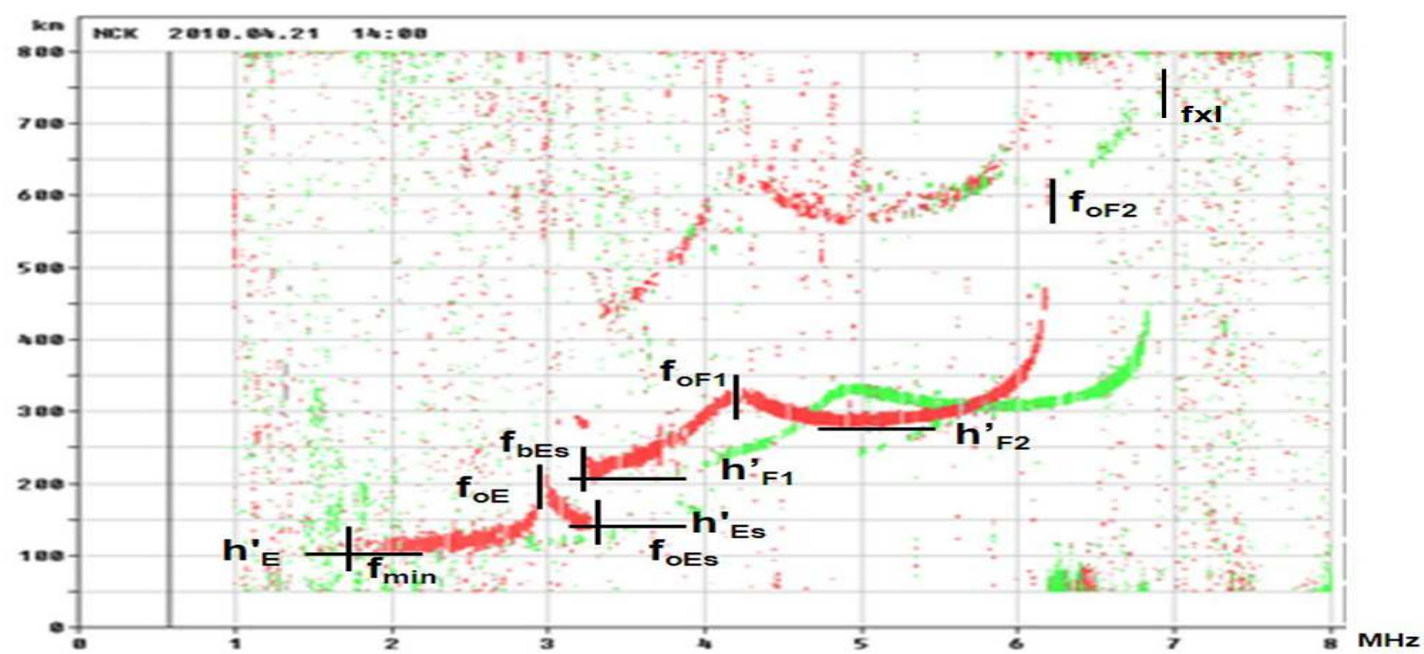

1. ábra. Ionogram a meghatározandó pozíciókkal és értékekkel 
A kiértékelés célja az ionoszféra rétegek és jellemző pontjaik azonosítása (digitalizálása). A manuális digitalizálás szubjektív hibákkal terhelt. A kiértékelés minőségét és sebességét jelentősen befolyásolja a kiértékelő személy tapasztalata és gyakorlata. Pontatlansága mellett jelentős élőerőt köt le, és kapacitás hiányában intézetünkben jelentős számú ionogram vár még kiértékelésre, ezért indokoltnak látszott a folyamat felgyorsítása automatizálás révén.

\section{Az ionogram kiértékelés jelene}

A humán ionogram feldolgozás betanítással kezdődik, mert a valós ionoszféra rétegek $(\mathrm{E}$, $\mathrm{E}_{\mathrm{s}}, \mathrm{F}_{1}, \mathrm{~F}_{2}$ ) ordinary (piros pontok az 1. ábrán) visszhangja mellett az extraordinary (vízszintesen eltolt zöld) és a másodlagos (függőlegesen eltolt, többszörös visszaverődésü) reflexiós rétegek is megjelenhetnek a képen. Egy réteg képe az ionogramon vonalszerü folt, mely foltok akár összecsúszhatnak, illetve szét is szakadhatnak, ami tovább nehezíti azonosításukat. A rétegek kialakulása függ a mérés időpontjától is, ezért csak abban lehetünk biztosak, hogy a legfelsö, $\mathrm{F}_{2}$ réteg biztosan elöfordul, ezért az $\mathrm{f}_{\mathrm{OF} 2}$ határfrekvencia minden ionogramon megtalálható. Tudjuk továbbá, hogy $80 \mathrm{~km}$ alatti és $500 \mathrm{~km}$ feletti réteg nem fordulhat elö - tehát ami ott van, csak zaj lehet.

A kiértékelés automatizálásának igénye már korábban felmerült, pl. az Artist programot [2] amerikai kutatók (Massachusetts University) fejlesztik több mint 25 éve, közvetlen elödje az UMLCAR SAO-X DIDBase [1] program volt. Olasz kutatók fejlesztik az Autoscala programot [3]. Mindkét program 95\%-os valószínüséggel határozza meg az ionogram jellegzetes pontjait legfeljebb 0,25-0,75 MHz és 25-75 km hibával [6], ami az elméleti felbontás 10-100 szorosa! Alkalmasak viszont többféle ionoszonda regisztrátumának elemzésére.

\section{Az ionogram kiértékelés jövője}

Az automatizált, számítógéppel támogatott ionogram feldolgozás előnyei:

a. Gyorsabb, pontosabb, kevesebb élőerőt igényel,

b. Egyszerüsíti az utófeldolgozást és a 'hátralék' feldolgozását,

c. Lehetővé teszi a sürübb mintavételezést (ez jelenleg a GGI-ben fél óra),

d. Feldolgozás után az ionogram tömörebben, függvényekkel tárolható,

e. Valós időben képes automatikusan elemezni az ionoszonda adatokat, ezért riasztásra is alkalmas pl. ürvihar esetén [5].

\section{Az ionogram kiértékelés matematikai modellje}

Az ionogram modellünkben egy raszteres digitális kép, eszerint kezeljük és elemezzük. Egyidejüleg az ionogramnak csak egyik színét vizsgáljuk (elsősorban az ordinary komponenst), ezért az ionogramot fekete-fehér digitális képnek tekintjük. A nem vizsgált színeket (és később az elkülönített zajt is) a háttérszínnel helyettesítjük. Egy átlagos ionogramon a színes pixelek száma többszázezer, ezért elemzése időigényes. A zajos digitális képen a klaszteranalízis összevonás és felosztás módszereivel keressük meg a releváns ionoszonda visszhangokat, ahol egy klaszter (osztály) a kép azon része, mely az ionoszféra adott réteghatárához tartozó visszhangokat tartalmazza - ez a gyakorlatban egy vonalszerü foltja a képnek. 


\section{Az ionogram kiértékelés algoritmusa}

Folt a kép azon összefüggő része, melynek bármely két pontja összeköthető azonos színü, szomszédokon átvezető úttal (foltkeresés rekurzív algoritmussal) - ebben az értelemben egy ionogram még több ezer foltot tartalmaz!

Vonjuk össze azon foltokat (ugyanis mérési hiba is okozhatja az elkülönülést), melyeknek a legközelebbi szomszéd elv szerinti L1 norma távolsága adott korlát alatti (default 4 pixel) - így küszöböljük ki az ionogram szakadási pontjait.

Az összevonások után ellenőrizzük a foltokat: ha egy folt pixeleinek száma adott korlát (default 160) alatti (vagyis túl kicsinek tünik), akkor a foltot zajnak tekintjük és töröljük ezután már csak kb. tucatnyi foltot kell megvizsgálni.

Akkor tekintünk egy foltot egy ionoszféra réteg visszhangjának, ha rá úgy illeszthető parabola, hogy az illesztés átlagos hibája (a szórás) kisebb egy előre adott (default 10 pixel) paraméternél, vagyis a folt vonalszerü.

Tehát csak a sokelemü, vonalszerü foltokat tekintjük az ionogram részének, és a foltot az alsó burkolójára illesztett függvény (parabola vagy hiperbola) paramétereivel tárolom az érvényességi frekvencia-határokkal együtt.

Ha a folt ugyan kiterjedt volt, de a parabolaillesztés mégsem sikerült (4. ábra), megvizsgáljuk az okát: lehet, hogy a különböző ionoszféra rétegekhez tartozó visszhangok összecsúsztak, ami onnan ismerhetö fel, hogy bár a folt váza folytonos görbének látszik, de a csatlakozási pontban töréspontja van (2. ábra). Ekkor a törésponttól balra eső pontokra illesztett egyenes meredeksége jelentősen eltér a jobbra található pontokra illesztett egyenes meredekségétöl, más szóval a töréspontban a bal és jobboldali differenciahányadosok jelentősen különböznek.

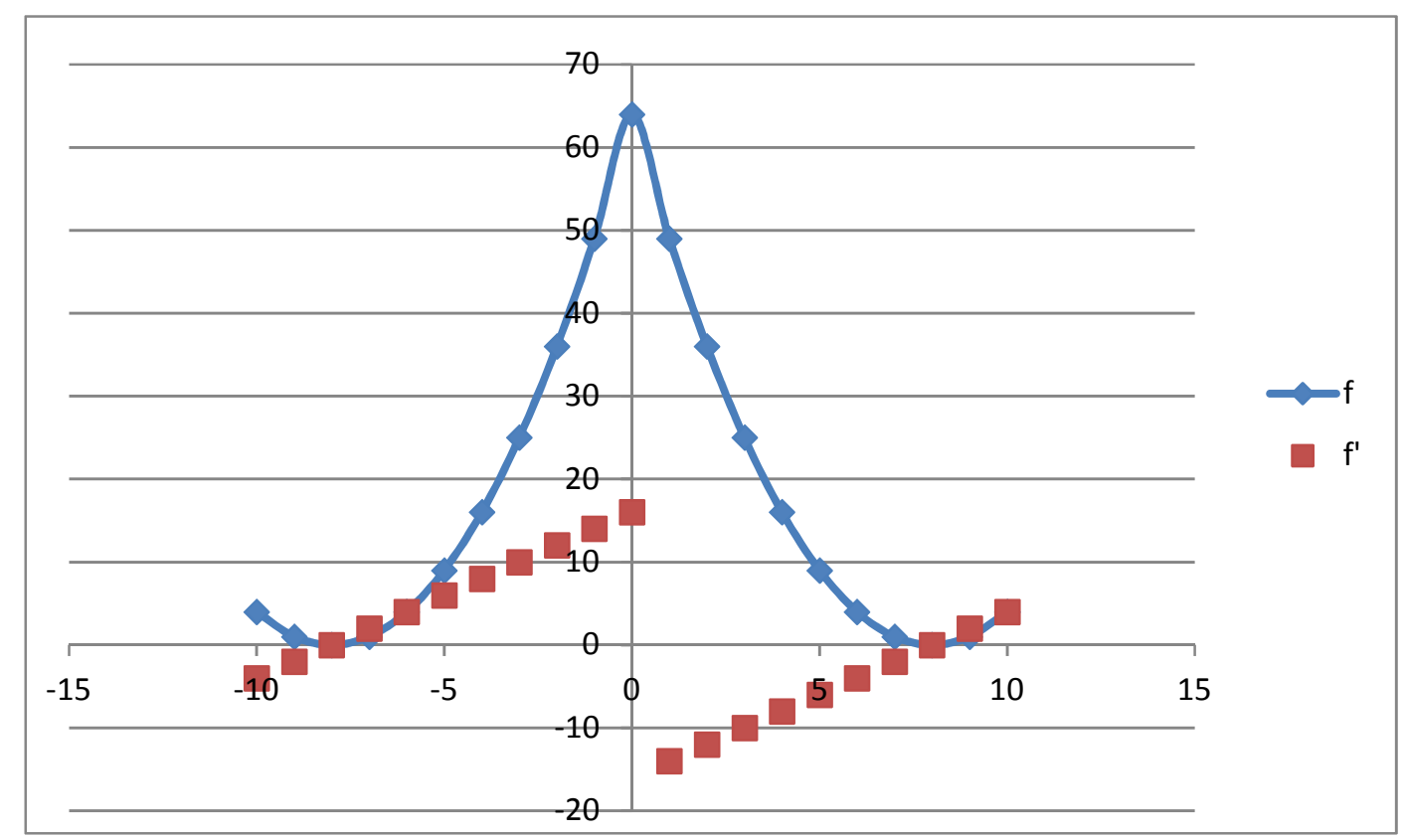

2. ábra. Metsző parabolák és deriváltjaik viselkedése a töréspontban

A klaszter vágási frekvenciáját úgy keressük meg, hogy a folt minden frekvenciájához meghatározzuk a differencia-hányadosok bal- és jobboldali határértékét; ahol a különbségüknek maximuma van, és ennek mértéke 2-nél nagyobb, ott a foltot kettévágjuk, a 
részfoltokat új klaszternek tekintjük (5. és 6. ábra), és visszalépünk a foltok nagyságának ellenőrzésére.

Ha nem sikerült a parabolaillesztés és szakadási pontot sem találtunk az előző pont szerint, akkor a foltot (klasztert) nagyságától függetlenül zajnak nyilvánítjuk, és töröljük.

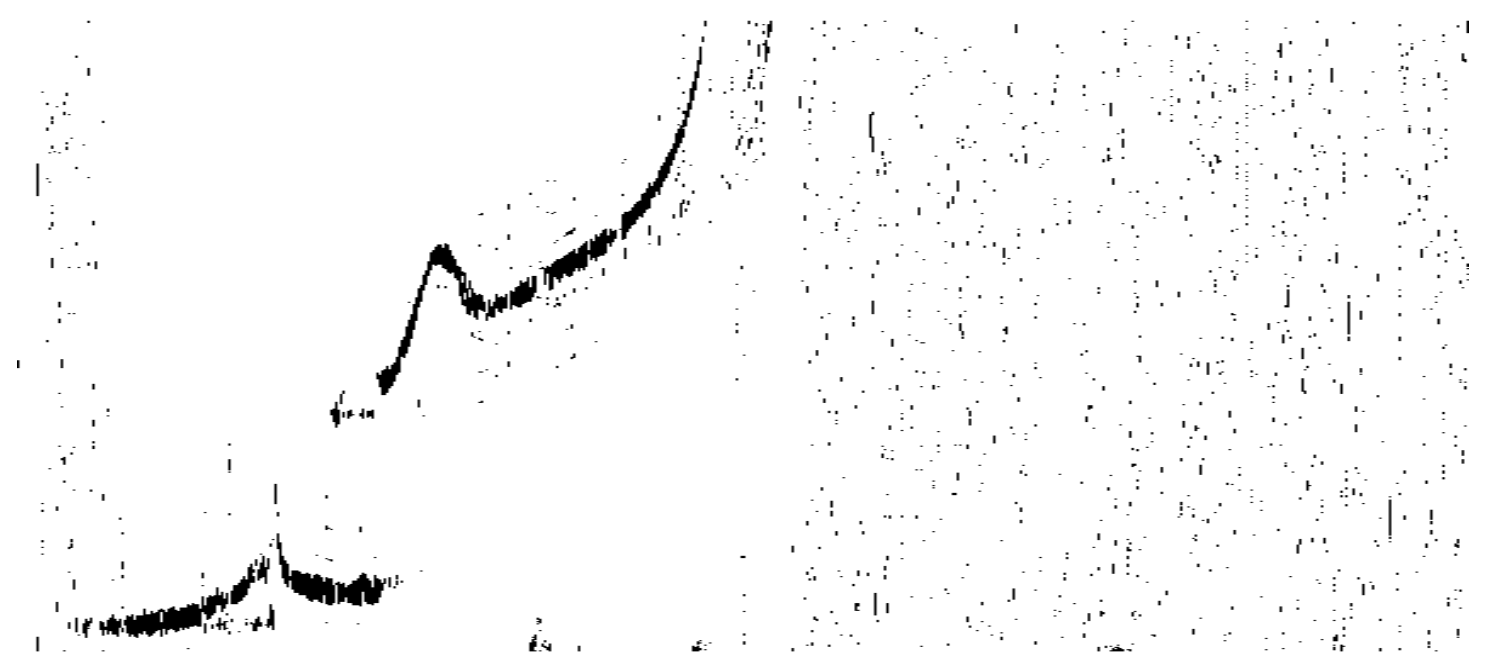

3. ábra. Egy alul (80 km-ig) és felül (500 km felett) törölt ordinary ionogram

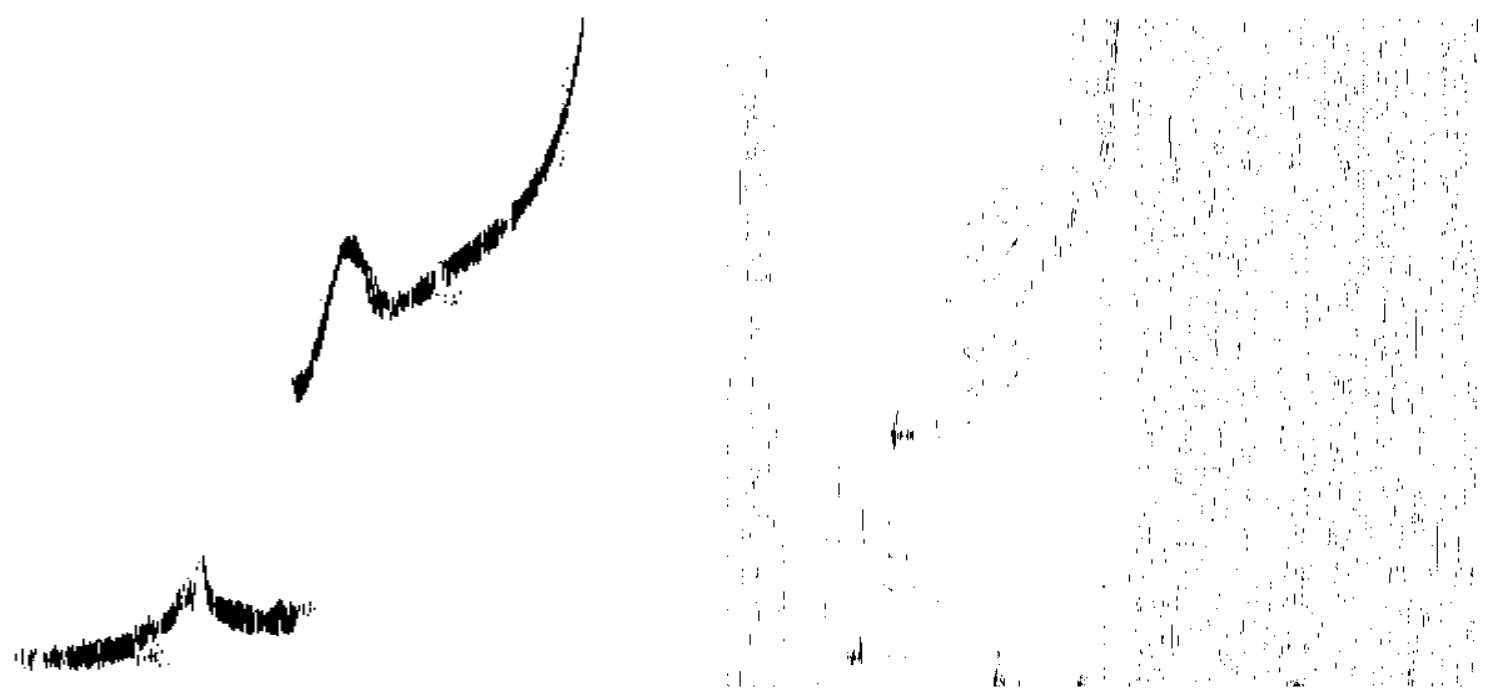

4. ábra. A 3. ábra ionogramjának releváns foltjai (balra) és a zaj (túl kicsi, vagy nem vonalszerú foltok) a jobb oldalon 

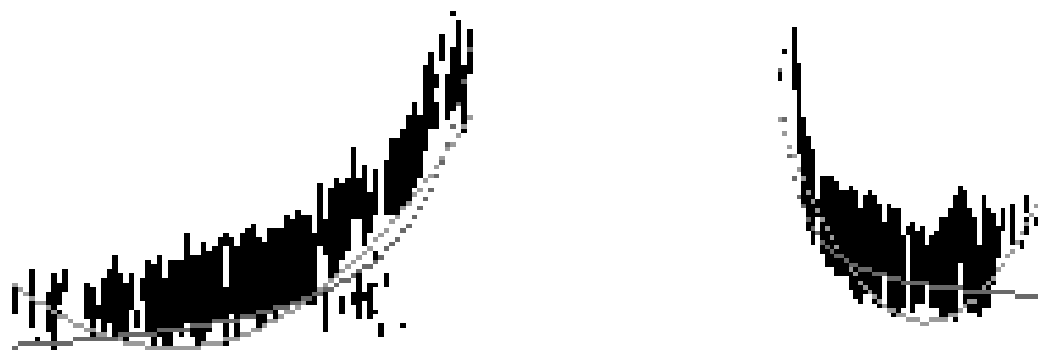

5. ábra. A szétvülasztott $E$ és Es ionoszféra rétegek visszhangja az illesztett görbékkel
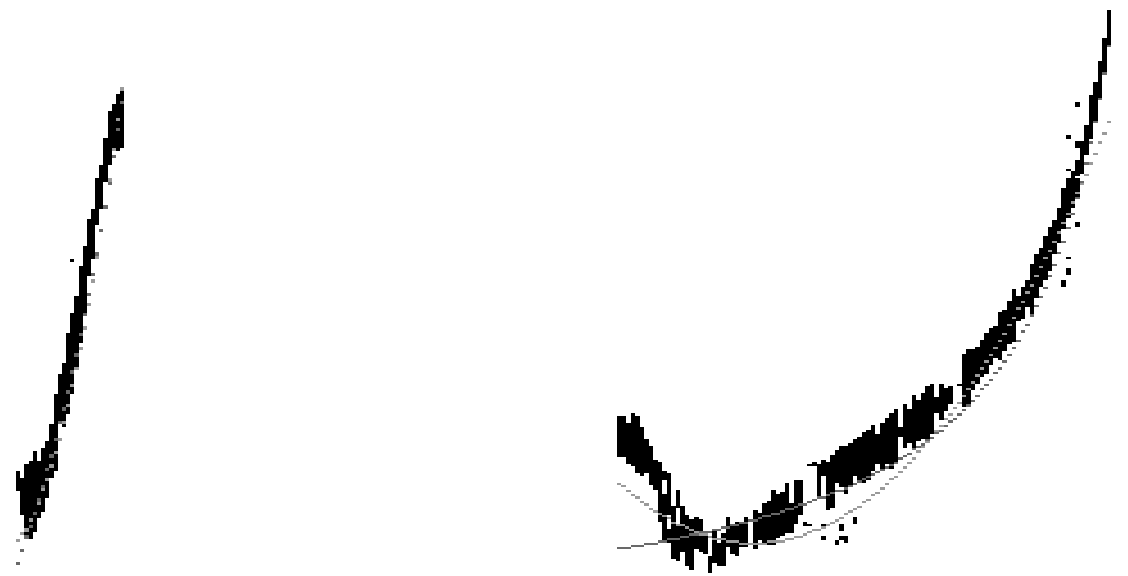

6. ábra. A szétválasztott $F_{1}$ és $F_{2}$ ionoszféra rétegek visszhangja az illesztett görbékkel

\begin{tabular}{|c|c|c|c|c|c|c|}
\hline $\min \mathrm{kHz}$ & magasság & $\max \mathrm{kHz}$ & magasság & $\mathrm{b}_{0}$ & $\mathrm{~b}_{1}$ & $\mathrm{~b}_{2}$ \\
\hline $1575(\mathrm{fmin})$ & $100,2 \mathrm{~km}$ & $3625\left(\mathrm{f}_{\mathrm{OE}}\right)$ & $127,7 \mathrm{~km}$ & 266,1 & $-0,1284$ & $2,8 \mathrm{e}-05$ \\
\hline $3650\left(\mathrm{f}_{0 \mathrm{E}}\right)$ & $143,6 \mathrm{~km}$ & $5000\left(\mathrm{f}_{\mathrm{OEs}}\right)$ & $129,5 \mathrm{~km}$ & 1623,6 & $-0,6685$ & $7,6 \mathrm{e}-05$ \\
\hline $4750\left(\mathrm{f}_{\mathrm{bEs}}\right)$ & $250,7 \mathrm{~km}$ & $5375\left(\mathrm{f}_{\mathrm{OF} 1}\right)$ & $351,0 \mathrm{~km}$ & 5555,4 & $-2,26$ & $2,4 \mathrm{e}-04$ \\
\hline $5375\left(\mathrm{f}_{\mathrm{OF} 1}\right)$ & $329,9 \mathrm{~km}$ & $8075\left(\mathrm{f}_{\mathrm{OF} 2}\right)$ & $447,4 \mathrm{~km}$ & 2696,1 & $-0,5828$ & $4,8 \mathrm{e}-05$ \\
\hline
\end{tabular}

1. táblázat. Az ionoszféra rétegek visszhangjára illesztett $h(f r)=b_{0}+b_{1} \cdot f r+b_{2} \cdot f^{2}$ parabolák

\begin{tabular}{|c|c|c|c|c|c|c|}
\hline $\min \mathrm{kHz}$ & magasság & $\max \mathrm{kHz}$ & magasság & $\mathrm{a}$ & $\mathrm{b}$ & $\mathrm{c}$ \\
\hline $1575(\mathrm{fmin})$ & $89,97 \mathrm{~km}$ & $3625\left(\mathrm{f}_{\mathrm{OE}}\right)$ & $139,1 \mathrm{~km}$ & 112,16 & -17906 & 3869 \\
\hline $3650\left(\mathrm{f}_{\mathrm{OE}}\right)$ & $151,7 \mathrm{~km}$ & $5000\left(\mathrm{f}_{\mathrm{OEs}}\right)$ & $114,5 \mathrm{~km}$ & 149,28 & 4972 & 3556 \\
\hline $4750\left(\mathrm{f}_{\mathrm{bEs}}\right)$ & $245,7 \mathrm{~km}$ & $5375\left(\mathrm{f}_{\mathrm{OF} 1}\right)$ & $348,5 \mathrm{~km}$ & 76,07 & -446144 & 6523 \\
\hline $5375\left(\mathrm{f}_{\mathrm{OF} 1}\right)$ & $308,4 \mathrm{~km}$ & $8075\left(\mathrm{f}_{\mathrm{OF} 2}\right)$ & $471,7 \mathrm{~km}$ & 369,15 & -135436 & 8596 \\
\hline
\end{tabular}

2. táblázat. Az ionoszféra rétegek visszhangjára illesztett $h(f r)=a+b /(f r-c)$ hiperbolák 


\section{A program továbbfejlesztésének lehetséges irányai}

A program egyelöre külön kezeli az ionogram ordinary (piros) és extraordinary (zöld) görbéit - mivel egyik a másikból eltolással állítható elő, ezért a hiányos ordinary görbék extraordinary párjuk ismerete alapján kiegészíthetők; sajnos, a szakirodalom szerint olyan mérési hiba is elöfordulhat, amikor az ordinary és extraordinary görbék teljesen felcserélődnek

Az ionogram görbék függőleges aszimptotáinak ( $f_{0 \mathrm{E}}, \mathrm{f}_{\mathrm{bEs}}, \mathrm{f}_{0 \mathrm{~F} 1}, \mathrm{f}_{0 \mathrm{~F} 2}$ ) meghatározását hiperbola-illesztéssel próbáltuk pontosítani. Sajnos a hiperbolaillesztés pontossága egyrészt nem érte el a parabola-illesztés pontosságát, másrészt sokkal időigényesebb volt, és az aszimptoták pozicióját (a 2. táblázat c paramétere) durvábban adta vissza, mint a leolvasott intervallum-korlátok. A még ajánlott tangensfüggvény illesztést nem sikerült elfogadható hibával kivitelezni, a szokásos ionogram görbékre a függvény rosszul illeszthető.

A másodlagos (reflexiós) visszhangok - ha vannak - görbéit törölni kell, mert érdektelenek.

A feldolgozás után kapott paraméteres görbéket egy szakértői (mesterséges intelligencia) rendszer elemezhetné tovább az ionoszféra rétegek azonosítása és a jellegzetes pontok meghatározása végett, melynek a szakirodalom szerint a mérés földrajzi helyét és időpontját (évszak, napszak) is figyelembe kell vennie.

\section{7. Összefoglalás}

Az ionogramok automatikus kiértékelését végző új program nagyon jó hatásfokkal képes elkülöníteni a zajt a releváns információtól, helyesen választja szét az ionoszféra rétegek visszhangját, és az ionogram releváns görbéit parabolaként tárolva lehetővé teszi azoknak egy későbbi, szakértői rendszer bázisú azonosítását.

\section{Irodalomjegyzék}

[1] Fox, M.W. and Blundell, C., 1989. Automatic scaling of digital ionograms. Radio Science, 24, 747-761. http://dx.doi.org/10.1029/RS024i006p00747

[2] Galkin, I.A., Reinisch, B. W., Grinstein, G. Khmyrov, G. Kozlov, A. Huang, X. and Fung, S. 2004. Automated Exploration of the Radio Plasma Imager Data, J. Geophys. Res., 109, A12210, http://dx.doi.org/10.1029/2004JA010439

[3] Scotto, C. and Pezzopane, M., 17-24 August 2002. A software for automatic scaling of foF2 and MUF(3000)F2 from ionograms, Proceedings of URSI 2002, Maastricht.

[4] Reinisch, B.W. and Huang, X., 2001. Deducing topside profiles and total electron content from bottomside ionograms, Advances in Space Research, 27, 1, 23-30. http://dx.doi.org/10.1016/S0273-1177(00)00136-8

[5] Reinisch, B. W., Huang, X., Galkin, I. A., Paznukhov, V. and Kozlov, A., 2005. Recent advances in realtime analysis of ionograms and ionospheric drift measurements with digisondes, J. Atmos. and Solar-Terr. Phys., 67, 1054-1062. http://dx.doi.org/10.1016/j.jastp.2005.01.009

[6] Stankov, S.M., Jodogne, J.C., Kutiev, I., Stegen, K., Warnant, R., 2012. Evaluation of automatic ionogram scaling for use in real-time ionospheric profile specifikation, Annals of Geophysics, 55, 2, 283291. http://dx.doi.org/10.4401/ag-4976 